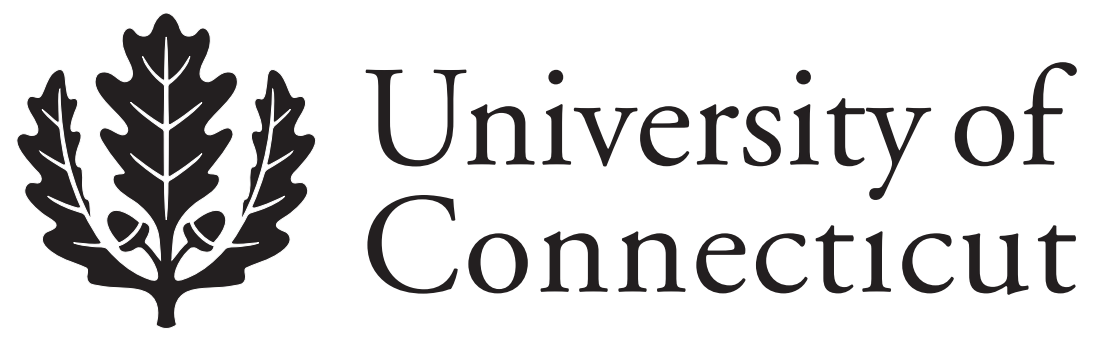

Department of Economics Working Paper Series

Public School Choice and Integration: Evidence from Durham, North Carolina

Robert Bifulco

University of Connecticut

Helen F. Ladd

Duke University

Stephen Ross

University of Connecticut

Working Paper 2007-41

October 2007

341 Mansfield Road, Unit 1063

Storrs, CT 06269-1063

Phone: (860) 486-3022

Fax: (860) 486-4463

http://www.econ.uconn.edu/

This working paper is indexed on RePEc, http://repec.org/ 


\begin{abstract}
Using evidence from Durham, North Carolina, we examine the impact of school choice programs on racial and class-based segregation across schools. Theoretical considerations suggest that how choice programs affect segregation will depend not only on the family preferences emphasized in the sociology literature but also on the linkages between student composition, school quality and student achievement emphasized in the economics literature, and on the availability of schools of different types. Reasonable assumptions about how these factors differ for students of different races and socio-economic status suggest that the segregating choices of students from advantaged backgrounds are likely to outweigh any integrating choices by disadvantaged students. The results of our empirical analysis are consistent with these theoretical considerations. Using information on the actual schools students attend and on the schools in their assigned attendance zones, we find that schools in Durham are more segregated by race and class as a result of school choice programs than they would be if all students attended their geographically assigned schools. In addition, we find that the effects of choice on segregation by class are larger than the effects on segregation by race.
\end{abstract}

Journal of Economic Literature Classification: H31, I20, R28

The authors wish to thank Clara Muschkin for comments on the paper and Justin Knight for his efforts as a research assistant. We would also like to acknowledge the assistance and support received from North Carolina Education Research Data Center, especially Gary Thompson's assistance with student address data, from Bill Bartholomay at Durham Public Schools at the City of Durham, and from Rob Cushman from City of Durham Technology Solutions. 


\section{Public School Choice and Integration Evidence from Durham, North Carolina}

Two U.S. Supreme Court cases more than 50 years apart highlight the struggle over race and schooling in the U.S. At one end is Brown v. Board of Education (1954), which ended the de jure racial segregation of schools, and ultimately forced districts to integrate their schools. At the other is the 2007 Supreme Court ruling that prohibits districts from using race as a factor in the assignment of students to schools. ${ }^{1}$ During the period between the two rulings, attitudes about the potential for parental choice of schools to play a positive role in integrating schools have changed quite significantly. While choice programs served as a means for many white families to avoid racially integrated schools during the 1950s and the 1960s and, hence, represented a significant obstacle to racial integration, the 1970 s to the 1990 s witnessed the development of new choice programs, primarily in the form of magnet schools or controlled choice programs, intended to promote racial integration. At the same time that such programs gave families more choice over their children's schools, policy makers typically retained control over school assignments by placing limits on the extent to which individual schools could be racially unbalanced.

Now that the Supreme Court has ruled out the use of race-based considerations in school assignments, the question arises of what role parental choice of schools will play in the future with respect to racial or other forms of school segregation. On the one hand are those who fear that unfettered choice systems will increase school segregation. On the other are those who believe that choice programs can continue to play a positive role in integrating schools and may be the only option available in light of the recent Supreme Court decision.

\footnotetext{
${ }^{1}$ Parents Involved in Community Schools v. Seattle School District No. 1, No. 05-908. Argued December 4, 2006Decided June 28, 2007.
} 
The purpose of this paper is to shed light on this question by examining the effects of several types of school choice programs on school segregation in Durham, NC. This urban school district represents a useful case study not only because it provides parents with a variety of different choice programs, but also because none of those programs are explicitly restricted by race. Thus, the patterns we observe are in response to programs that are consistent with the new Supreme Court ruling. Further, as we discuss below, detailed data on student addresses, assigned school zones, and current schools makes it possible for us to determine which types of students opt for which types of schools and how those choices affect the peer groups of different types of students.

Only two previous studies have had access to this type of data: Saporito (2003) for Philadelphia and Cullen, Jabob, \& Levitt (2005) for Chicago. Both of these studies, however, focus on large, central city school districts which are composed predominantly of minority and low income students. Our study uses data from the Durham Public School system in North Carolina, which is a large countywide school district. Our study is the first of this type to examine the effect of choice on segregation in a school district that contains significant student diversity by race, income, and education level of the parents.

We begin with a conceptual framework that provides the foundation for the empirical investigation that follows. This framework starts with the well established sociological literature on the importance of parent and student preferences with respect to the mix of students or families in a school or neighborhood. We then expand that framework to include other factors that influence parents' decisions about where to send their children to school, such as school quality and the availability of schools of different types. The next sections describe the choice programs in Durham, the data we use, and our empirical analyses. The empirical analyses are 
divided into three parts. The first part examines students' decisions to opt out of their assigned schools, and examines how those decisions are affected by the peer compositions of the students' assigned attendance zones. The second set of analyses examine whether the students who opt out are choosing schools that are more or less segregated than their assigned school. The third set compares various indicators of racial and class segregation that emerge from Durham's school choice programs to what those same indicators would look like if all students attended their assigned neighborhood schools. We conclude with a discussion of policy implications.

\section{Segregation and School Choice}

School choice programs are understood here as programs that separate a family’s choice of school from its choice of residence. In addition to providing more schooling options for families compared to a mandatory school assignment program, such programs shift control over the composition of each school's students away from district policy makers in favor of parents. Our main research question is how such school choice programs are likely to affect student segregation. While racial integration remains a salient concern, many people are also concerned with the extent to which students who are challenging to educate, regardless of race, are concentrated in specific schools (Kahlenberg, 2000). Hence, we broaden the question to consider the effects of choice programs on segregation defined by class as well as by race.

\section{Preferences based on race and class}

Several theories emphasize the role of race and class based preferences in determining the level of school segregation when parents are given choices. One theory posits that school choice programs will increase segregation by making it easier for white or otherwise advantaged parents to avoid schools with proportions of minority or other disadvantaged students whom they wish to avoid. Following Saporito (2003), we refer to this theory as the outgroup avoidance 
theory and note that it is one of the explanations given for "white flight" in the context of school desegregation efforts. A second theory, which also implies that school choice will increase segregation, posits that parents of all races seek out educational environments where their students can be with students of similar backgrounds. We refer to this theory as neutral ethnocentrism. Finally, the high level of residential segregation in U.S. metropolitan areas suggests that choice might reduce racial segregation in schools by providing families access to schools that are more integrated than the neighborhoods available to them. School choice in this context liberates families from the residential constraints they face, and following Archbald (2003) we call this the liberation theory.

Several studies have shown that past efforts to desegregate schools generated "white flight” from U.S. central cities (Clotfelter, 1979; Coleman, Kelly \& Moore, 1975; Rossell \& Armor, 1996; Welch \& Light, 1987). The ability of white parents to avoid school desegregation efforts by changing where they live differs substantially across the country due to differences in the relative size of central city school districts. In the South where school districts tend to be coterminous with counties, urban school districts may contain a substantial fraction of the housing stock available within a metropolitan area, thereby limiting the ability of white parents to avoid integrated schools by moving to a different district (Clotfelter, 2004). To the extent that school officials construct school zones to promote racial integration in such a district, school choice programs provide a mechanism for white students to reduce their contact with minority student populations.

Such behavior would be consistent with outgroup avoidance theories, which argue that white, wealthier and more educated families will take steps to maintain their social status by distancing themselves from groups of lower standing (Bobo, 1999; Bonilla-Silva, 1996; Tauber 
\& James, 1982; Wells \& Crain, 1992). Considerable evidence for the outgroup avoidance hypotheses comes from studies of neighborhood preferences, which find that whites are not willing to live in neighborhoods with substantial percentages of minority, and particularly, black residents (Bobo and Zubrinsky, 1996; Clark, 1992; Farley et al., 1994; Timberlake, 2000). The outgroup avoidance hypothesis is also consistent with studies that find evidence of white parents avoiding schools with substantial minority populations (Bifulco \& Ladd, 2007; Brunner, Imazeki, Ross, 2006; Henig, 1996; Lankford, Lee, \& Wyckoff, 1995; Lankford \& Wyckoff, 1999; Saporito, 2003), as well as studies that find lower housing prices near schools with a large fraction of minority students (Clapp, Nanda, \& Ross, 2007; Downes \& Zabel, 2002; Kain, Staiger \& Riegg, 2005).

An alternative theory suggests that choices of social settings are motivated by a "neutral ethnocentrism" or desire to interact with those similar to oneself. "Neutral ethnocentrism" implies that black families (or outgroups more generally) are as likely to choose segregated over integrated environments as are white (or high status groups more generally). Limited evidence for black self-segregation in housing markets is provided by King and Mieskowski (1973) and more recently by Ihlanfeldt and Scafidi (2002). ${ }^{2}$

Like the outgroup avoidance hypothesis, neutral ethnocentrism predicts that school choice programs will increase school segregation. In contrast to the outgroup avoidance hypothesis, however, it predicts that increased segregation will be driven as much by black families opting out of majority white schools for majority black schools as by "white flight." Segregation that results from this mechanism might be more acceptable to some policy makers

\footnotetext{
${ }^{2}$ For evidence against the black self-segregation hypotheses see Cutler, Glaeser \& Vigdor (1999); Galster (1982); Krysan \& Farley (2002); and Yinger (1978).
} 
than segregation that results from outgroup avoidance or from social institutions explicitly designed to limit the opportunities of African Americans (Viteritti, 1999).

In contrast to the outgroup avoidance and neutral ethnocentrism theories, the liberation theory starts from the observation that some families are constrained in where they can live, and posits that programs to expand school choice could potentially decrease school segregation relative to the segregation that would occur with neighborhood-based school assignment zones. Although there has been some progress in reducing residential segregation over the last two decades, it remains pronounced in many metropolitan areas (Farley \& Frey, 1994; Iceland, 2004; Massey, 2001). To the extent that school districts assign students to schools by neighborhood, residential segregation translates into segregated schools. School choice programs that break the link between residential location and school attendance would reduce school segregation if families prefer schools that are more integrated than the neighborhoods in which they live.

This outcome is most likely to occur when residential opportunities are restricted in some way. Existing studies suggest several ways that residential opportunities may be restricted. The tipping processes described by Schelling (1971) can generate residential segregation even where differences in preferences between black and white households regarding racial composition are small, and racially integrated neighborhoods have proven difficult to maintain, even where substantial numbers of individuals are open to interracial settings (Yinger, 1995). Further, ample evidence indicates that the residential location choices of black families continue to be constrained by ongoing discriminatory practices as well as the legacy of historical discrimination (Ross, 2008; Ross \& Turner, 2005). Thus, many black families may find themselves and their children in more segregated settings than they might choose in less constrained housing markets. Bayer, McMillan and Rueben (2005) find that in many areas black families with high levels of 
income and education are forced to choose between neighborhoods with desirable schools or a high proportion of blacks, because very few neighborhoods combine both. These families are likely to use choice programs to select more integrated schools.

In addition, Ellen (2000) and Krysan (2002) argue that racial stereotypes play an important role in the perception of neighborhood quality. Although, racial stereotypes can also influence school choices, modern school accountability programs often make information on school quality - as least as crudely measured by test scores -- readily available. If parents have more information about school quality than they have about neighborhood quality, they might rely less on racial stereotypes in selecting schools than in selecting neighborhoods, and as a result, school choice programs could reduce school segregation relative to neighborhood assignment policies.

The Relationship between School Quality and Segregation

The sociology literature on school segregation has emphasized the importance of preferences regarding race and class, and has often overlooked other aspects of schools, such as student achievement, quality of instruction, school discipline, and programmatic offerings, that also may affect parental choices and the resulting patterns of segregation. How school choice affects segregation will depend on the importance parents place on these factors relative to the racial or socioeconomic composition of a school's students, and on the extent to which preferences regarding these other factors differ systematically across racial and socioeconomic groups.

Although the evidence on school preferences and whether these differ across groups is mixed, surveys of parents typically find the both white and minority parents place a high value on student achievement as typically measured by test scores and on instructional quality (Armor 
\& Peiser, 1998; Klietz, Weiher, Tedin, and Matland, 2000; Schneider, Teske, and Marschall, 2000). ${ }^{3}$ The situation is complicated, however, by the fact that a school's peer characteristics are a determinant of various measures of school quality. A massive array of studies dating back to the Coleman report document the strong relationship between race and class and student performance based on standard benchmarks, such as standardized test scores, grades and graduation rates (Campbell, Hombo, \& Matteo, 1998; Coleman, 1966; Duncan \& Brooks-Gunn, 1997; Ferguson, 2001; Jencks \& Phillips, 1998). As a result, regardless of instructional quality, schools with high proportions of white and college educated parents often exhibit high levels of academic achievement, which makes those schools attractive to many parents.

In addition, several studies demonstrate that instructional quality depends not only on the monetary resources available to the school, but also on the mix of students in the school. The presence of a large proportion of educationally advantaged students in a school may have positive effects on school quality through a variety of mechanisms. In addition to the possibility of positive spillover effects on motivation and learning from one student to another, it may affect discipline in the classroom and, through discipline, the time and resources available to support learning (Lazear, 2001). Also students from advantaged backgrounds may bring with them social capital in the form of parental input, and may make it easier for the school to attract high quality teachers. The latter occurs because high quality teachers often prefer to teach in schools with more motivated and high-achieving students (Clotfelter, Ladd, \& Vigdor, 2006; Lankford, Loeb \& Wyckoff, 2002).

\footnotetext{
${ }^{3}$ The most consistent finding from these surveys is that few parents in any group report that racial composition is an important consideration. However, Schneider and Buckley (2002), who observe internet search behavior of parents in Washington, D.C., provide evidence that lack of emphasis on socioeconomic characteristics and race in surveys of school preferences is due to socially desirable response bias.
} 
For students from educationally advantaged groups, e.g. white families with college educated parents, preference for high quality schools or schools with high levels of achievement will reinforce any preferences about peer composition associated with outgroup avoidance or neutral ethnocentrism and will tend to increase the pressure for segregated schools. Students from educationally disadvantaged groups, including minorities and those with less educated parents, in contrast, may face a tradeoff between the desire for high performing schools and the desire for settings with students who share a similar background. Without knowing how preferences are distributed within this group, we cannot make clear predictions about how their choices will affect segregation. .

In areas with high levels of residential segregation, strict neighborhood assignment policies are likely to result in high levels of school segregation. In this case, even if black and white parents have different preferences for school characteristics, expanding parental choice may not increase school segregation. In fact, school choice may reduce segregation if a substantial number of parents value integration, if white or college educated parents do not have a strong aversion to disadvantaged students per se, or minority parents place a high value on levels of student achievement relative to having their children in schools with large proportions of students from similar backgrounds.

\section{The Supply of Schools}

Finally, the effect on segregation of allowing choice is likely to depend on the available options. Evidence clearly shows, for example, that the availability of predominantly white schools and neighborhoods influenced the extent of white flight in response to desegregation efforts. (Clotfelter, 2004; Coleman, Kelly, \& Moore, 1975; Yinger, 1995). 
Complicating the analysis of options is the fact that options themselves are determined endogenously as part of the school choice process. Stated differently many of the school characteristics that matter to parents and students emerge in equilibrium as a result of individual choices. So, while the presence of predominantly minority schools may increase white flight directly, the fact that some families have an aversion to minority students, or a preference for high quality schools (assuming that race is correlated with school quality) will further increase the likelihood that predominantly segregated schools emerge from choice programs. In addition, the strength of the correlation between family background characteristics and achievement is itself endogenously determined. For example, if minorities gain access to more integrated schools as a result of school choice and benefit from the peer effects and higher teacher quality in those schools, the link between race and student performance might weaken. A weaker link between race and achievement might make white parents more willing to choose integrated schools. Alternatively, if increased segregation that results from choice programs negatively affects performance of minority students, incentives for white flight will increase. In either case, these feedback effects may make the long run effects of parental choices larger than any immediate effects.

Although the characteristics of the schools made available under a school choice program are ultimately shaped by individual choices, policy decisions still can play an important role. Policy decisions about resources and the location of schools, for instance, can influence the supply of schools that emerges in equilibrium. If parents prefer schools with more resources, the generous funding of schools in minority neighborhoods as part of a choice program may attract students from other neighborhoods with different family backgrounds. Also, the creation of specialized schools with specific themes, such as district wide magnet schools in science or 
theater, may draw students from across the district or even from other districts. In this way, school specialization can widen a school's catchment area beyond racially isolated neighborhoods, thereby reducing segregation. Working in the other direction, if choice schools seek to establish niches by offering curricula tailored to specific groups or neighborhoods, the expansion of parental choice might increase segregation.

The legal status of efforts to use school location, resource and programming decisions to promote integration remains unclear. Although the recent Supreme Court decision declared it unconstitutional for school officials to consider the race of an individual student in assigning students to schools, as the fifth vote in the majority, Justice Kennedy explicitly left open the possibility for choice programs that considered issues of race in design as long as they did not incorporate race into decisions related to individual students. Thus, choice programs where public authorities maintain control over these indirect policy levers, such as the offerings and location of magnet or charter schools, might provide one of the primary means left for policy makers to promote integrated schooling. ${ }^{4}$

In sum, how school choice programs are likely to affect school segregation depends on a number of interrelated factors. As a result, it is difficult to predict in any given context whether school choice programs will increase or decrease racial segregation. Instead, we must turn to the empirical evidence.

\section{Student Assignment Policies in Durham}

Our empirical analysis uses data on elementary and middle school students in Durham, North Carolina during the 2002-03 school year. The Durham Public School district is a

\footnotetext{
${ }^{4}$ Little is known about how school supply decisions, such as where to locate schools and what programs to offer, are made under magnet school and charter school programs. Questions about what types of incentives for promoting integration are created by these two types of programs are worth further investigation, but are beyond the scope of this discussion. The key point here, is that both magnet school and charter school programs provide mechanisms that allow public authorities to exercise some control over school supply decisions.
} 
countywide school system that serves approximately 32,000 students in 46 schools. Unlike many other large, urban districts in North Carolina and elsewhere, the Durham Public Schools have never been subject to a federal desegregation court order. Nonetheless, for a number of years the district used race conscious student assignment policies to promote racial balance. Since 1999, however, all student assignment decisions in Durham Public Schools have been race blind.

The district relies primarily on contiguous, geographic attendance zones to determine student school assignments. There are 21 elementary school attendance zones and six middle school attendance zones. The majority of students in the district attend their assigned school. As is the case in many urban districts across the country, however, layered on top of the district's geographic assignment plan are several policies that provide parents the opportunity to opt out of their assigned school to attend another public school.

First, the district has long had a very liberal student transfer policy. The current policy states that district officials can grant a transfer request for any reason, and must grant any requested transfer provided it is submitted before the school year, space is available at the requested school, and the student has an acceptable record of attendance and behavior for the prior school year. Our analysis indicates that about 13 percent of the students transfer from their assigned school to another zoned school. By a "zoned" school we mean a school other than a magnet, year-round, or charter school.

During 2002-03, the district operated six elementary and two middle magnet schools. The educational programs in each magnet are designed around a specific theme, and each magnet offers unique enrichment opportunities. The elementary magnet schools offer various themes but none are primarily targeted for high achieving students. One of the middle school 
magnets offers an International Baccaulaureate Middle Years Program which is a rigorous, college prep curriculum. The other magnet school serves grades six through twelve and offers extensive visual and performing arts programs. Any student residing in Durham is eligible to attend any of the magnet schools. Enrollment in a magnet school is by application only and admission is determined entirely by a computerized lottery. Two exceptions at the elementary school level, but not the middle school level, are that students in walk-zones established around each magnet school as well as siblings of current students are given preferences in the admission process. Prior to 1999, magnet school lotteries were designed to meet racial composition guidelines. Since that year, however, all magnet school admissions have been race blind.

The district also operates three elementary schools and two middle schools on a yearround calendar, which divides the year into 9-week quarters with a three week break between each quarter. Students in year-round schools attend the same number of days as students in traditional schools and have the same basic instructional program. The three elementary year round schools each have a regular attendance zone similar to those for other elementary schools. However, students in those zones who do not want a year-round calendar are guaranteed admission at a neighboring school. The remaining seats in the year-round schools are available by application. One of the two year-round middle schools does not have a regular attendance zone and all admissions are by application. Among applicants from outside a school's regular attendance zones, all admissions to the year-round schools are made by lottery.

In addition, to these schools of choice operated by the district, Durham is home to several charter schools. For a number of years, Durham has had a higher concentration of charter schools than any other district in the state. Charters in North Carolina are granted by the state and charter schools are operated independently of the local school district. Any student can 
apply for enrollment in a charter, with admission determined by lottery. Although the district does not provide transportation for students to charter schools, state law requires each charter school to develop a transportation plan so that transportation is not a barrier to any student who lives in the local school district where the school is located. During the 2002-03 school year, seven charter schools in Durham served students in grades 3 through 8. The charter schools are all small and have a variety of grade configurations. All but one school serves at least one or more elementary school grades, and all but one serves one or more middle school grades.

\section{Data}

The data for the analyses presented here are drawn from two administrative sources: the North Carolina Department of Public Instruction’s End of Grade (EOG) test files and Durham Public School's student transportation files. The EOG files contain a record for every public school student in grades 3 through 8, including charter schools students and students without test scores as well as those with valid test scores. In addition to information on test scores, the EOG files indicate what school the student attended, the student's race/ethnicity and the highest level of education obtained by the student's parents. The transportation files include an address for every student for which the district is responsible for providing transportation. These files were linked together and made available to us by the North Carolina Education Research Data Center. In addition, we obtained school attendance zone boundary files from the County of Durham that allow us to place individual student addresses into school attendance zones established by the Durham Public Schools.

Two issues in assembling these data are important for the analyses that follow. First, because the Durham Public School district does not provide transportation for charter school students, we do not have addresses for the majority of charter schools students residing in 
Durham during the years they attended charter schools. We do have current year addresses for students who transferred into a charter school during the school year. In addition, because we have transportation files for multiple years between 1997-98 and 2005-06, we have addresses for charter school students who are observed at some point in other Durham public schools. All but two of the charter schools in Durham end by grade eight, and the two that serve older students end in tenth grade and begin after third grade. Thus, most of the charter school students between grades six and eight during the 2002-03 school year had transferred to a regular Durham public high school by 2005-06, and many of those that did not are observed in a Durham elementary school in earlier grades not served by their charter school. Thus, we were able to obtain addresses for 70 percent of charter school students in grades six through eight for the 2002-03 school year. Because younger students are less likely to have aged out of their charter school by 2005-06, we have address data for only 45 percent of charter school students in grades three through five. The possibility that some charter school students might have moved between the year we observe their addresses and the year they enrolled in a charter school introduces some measurement error into our analysis, but the error is likely to be small.

Second, one of the year-round schools, representing about one-third of the middle school students who have chosen the year-round option, is housed in the same building as a traditional, zoned middle school. The student test score files do not distinguish students who attend the year-round school housed in this building from the students in the traditional program. To distinguish these two groups, we assume that any student in that school, who does not live in the attendance zone for the traditional, zoned school is in the year-round program, and that all other students in the building are in the traditional program. This process results in an assignment of approximately the correct total number of students to each school. Undoubtedly, however, some 
students are misclassified. For purposes of computing a student's average peer characteristics, we treat the two schools as one. Thus, the peer characteristics for students that we assigned to the year-round program are assumed to be the same as for those assigned to the traditional school program.

Table 1 presents summary information on the students in our study. The first and third columns provide information on all students in grades 3-5 and grades 6-8 in the EOG files. Not including students in alternative schools, who are excluded from all of the analysis the follow, ${ }^{5}$ approximately 60 percent of both elementary and middle school students attend their assigned school. Forty percent of elementary school students opt out of their assigned school-12.4 percent choose a magnet school, 15.8 percent transfer to another zoned school, 6.2 percent opt for a year-round school, and 5.8 percent choose a charter school. Among middle school students, 14.2 percent choose one of the two magnet schools, 10.4 percent transfer to another zoned school, 10.4 percent choose one of the two year-round schools, and 5.2 percent attend a charter school. The lower portions of the table show that approximately 60 percent of students are black, 25 to 28 percent are white, and 7 to 9 percent are Hispanic. Just over 38 percent of elementary school students and 48 percent of middle school students have a parent with a two- or four-year college degree.

The second and last columns describe the sample of students for whom we have address data. Overall, we have addresses for 97.9 percent of the students in grades 3 through 8 in 200203, although this percentage is lower for charter schools, particularly at the elementary school level. All the analyses that follow are conducted using the set of students for whom we have

\footnotetext{
${ }^{5}$ Alternative schools include a school at the Duke medical center for students experiencing long-term hospital stays, and a school for students with behavioral or other issues. Assignment of these students is based neither on geographic assignment zones nor on parental decisions.
} 
address data, and exclude students attending alternative placement schools. This sample includes 7715 students in grades 3-5, and 7204 students in grades 6-8.

\section{Empirical Analysis and Results}

Our empirical analyses are designed to shed light on three issues. First, we examine the decision to opt out of one's assigned school, and determine whether there are systematic differences in the likelihood of opting out by race, parent education, or student achievement level. Second, we consider the choices of students who have opted out of their assigned school, and compare the peer composition in the schools they choose to the peer composition in the assigned school they forego. Third, we compare actual measures of segregation by race, parent education level, and achievement to what those segregation measures would be if all students attended their assigned school. Throughout, we assess the extent to which the observed patterns of choices are consistent with the outgroup avoidance, minority self-segregation, and liberation models of behavior.

All of our analyses are conducted separately for students in grades 3 through 5 and grades 6 through 8. The contexts in which elementary and middle school students in Durham choose schools differ in two ways. First, because the district is divided into 21 elementary school attendance zones, but only 6 middle school zones, elementary schools draw from smaller geographic areas than middle schools. As a result, segregation across elementary school attendance zones is greater than across middle school zones. The percent black ranges from 18.4 to 91.0 across elementary attendance zones, but only from 45.8 to 71.3 across middle school attendance zones. Similarly the percent of students with college educated parents ranges from 16.1 to 69.5 at the elementary school level, but only from 41.5 to 54.5 at the middle school level. Second, because the programs of the choice schools, and particularly the magnet schools, offered 
at the elementary and middle school grades differ in ways described above, comparing the pattern of choices in the elementary and in middle schools provides an opportunity to examine how these differences in context mediate the effect of school choice on segregation.

\section{The Decision to Opt Out}

The outgroup avoidance hypothesis predicts that white students and students with college educated parents will be more likely to opt out of schools with higher percentages of black students or lower percentages of students with college educated parents, and when they have ready access to alternatives that have higher percentages of white students and students with college educated parents than their assigned school. Such choices might be motivated either by race and class sentiments or by the fact that schools with more advantaged students tend to have higher levels of achievement and perhaps higher quality programming. In either case outgroup avoidance is likely to increase school segregation by race, class and achievement.

The neutral ethnocentrism hypothesis generates similar predictions as the outgroup avoidance hypothesis for white and college educated families, but the predictions differ for black students and students whose parents do not have a college degree. According to the neutral ethnocentrism hypothesis, such students will be more likely to opt out of schools with a lower percentage of students like themselves, and when they can readily access alternatives to their assigned school that have higher percentages of black students and students whose parents lack a college education. As we discussed above, students from disadvantaged backgrounds often face a tradeoff between choosing a school with students more like themselves and choosing a high achieving school. For our purposes here, the neutral ethnocentrism hypothesis is understood to maintain that for a substantial proportion of black students and students whose parents lack a college education, preferences for attending school with peers like themselves will be more 
influential than considerations of student achievement.

The liberation model predicts that students from families whose residential choices are constrained may use school choice to select more integrated schools or schools with more advantaged students and higher levels of achievement. In contrast to neutral ethnocentrism, the liberation model predicts the black students and students whose parents lack a college education will be more likely to opt out of schools with concentrations of students from disadvantaged groups that are located near schools with higher proportions of students from advantaged groups.

We test for evidence in support of these three sets of hypotheses by estimating probit models to predict the likelihood that different groups of students opt out of their assigned school. Predictors used in the elementary school model include the percent black and the percent college educated in the student's assigned attendance zone. Ideally, we would also include measures of student achievement in the assigned attendance zone to separate the influence of race and class from that of school achievement. However, measures of average achievement are so highly correlated with percent black and percent college educated parents that the effect of achievement in the student's attendance zone on the choice to opt out can not be separately estimated with any precision. At the middle school level, percent black and percent college educated were also too highly correlated to allow us to separate their effects on the likelihood of opting out, so only percent black is included in the middle school models.

To capture variation across students in access to schools with different peer compositions than in their assigned attendance zone, we use measures of the distance between the student's residence and various types of schools. Recent studies show that a school's distance from home influences the likelihood that a student will use school choice programs to enroll in that school (Bifulco \& Ladd, 2007; Cullen, Jacob \& Levitt, 2005; Hastings, Kane, \& Staiger, 2006). The 
distance measures of interest are miles to the nearest school that has a percent black (or white) 15 points higher than in the student's assigned attendance zone and miles to the nearest school where the percent of students with college educated parents is 10 points higher than in the assigned attendance zone. ${ }^{6}$ The shorter these distances, the more access one has to schools with significantly different peer compositions than the assigned school.

In addition, to these distance and peer composition variables, we include as control variables, each student's own achievement level, miles to her assigned school, and the average number of miles to the three nearest schools. Controlling for the distance to the three nearest schools is necessary to distinguish the effect of having access to schools with different peer compositions from the effect of having access to more schools generally. Each model is estimated separately for white students with college educated parents, white students whose parents do not have a college education, black students with college educated parents, and black parents whose parents lack a college education. ${ }^{7}$

Table 2 presents summary statistics for each of the variables used in the model. The second row of each panel indicates that black students are more likely to opt out of their assigned schools than are white students, and that the difference is particularly marked among elementary grade students. Because black families tend to have less income and face more housing market discrimination than white families, the ability of blacks to choose neighborhoods zoned for schools that match their preferences is typically more constrained, which might explain their greater likelihood of opting out of their assigned schools. ${ }^{8}$ The fact that black students tend to

\footnotetext{
${ }^{6}$ Differences of 15 percent for percent black and 10 percent for percent of college educated parents were selected after examining the distributions of these percentages across schools. The cutpoint percent black is higher than for percent college educated because the range of values for the former is greater than for the latter.

${ }^{7}$ Populations of Hispanic students and students of other ethnicities were not large enough for these analyses.

${ }^{8}$ Hispanic families, however, whose housing market choices may be similarly constrained, are less likely than both black and white families to opt out of their assigned school.
} 
live in denser areas close to the center of Durham and nearer to a number of different schools might also help to explain their greater propensity to opt out of their assigned school.

At the elementary school level parents who lack a college education and those who have a college education are equally likely to use choice programs to select a school other than their child's assigned school. At the middle school level, however, college educated parents are more likely to opt out than parents who do not have a college education. This difference between choices at the elementary and middle school levels probably reflects the differences in the attendance zones described above. The wider range of elementary school attendance zones compared to middle school zones, renders college educated parents better able to use residential location to choose an elementary school zone that matches their preferences, making them less reliant on choice programs than comparable parents at the middle school level. Analyses not shown here also reveal that the greater likelihood that college educated parents have of opting out at the middle school level is driven entirely by those opting out to magnet schools. Apparently, the themes of the magnet schools at the middle school level help to attract college educated parents much more strongly than those of elementary school magnets. ${ }^{9}$

The estimated probit models are presented in Table 3. Considering the control variables first, a student's own achievement does not influence his or her likelihood of opting out in the elementary school grades. At the middle school level, however, high achieving students are more likely to opt out than low achieving students. In keeping with expectations, the further a student lives from his or her assigned school, the more likely the student is to opt out, and the more distant are the alternatives to the student's assigned school, the less likely the student is to

\footnotetext{
${ }^{9}$ At both the elementary and middle school levels, the magnet schools are located in the City of Durham in predominantly minority neighborhoods. Thus, location of magnet schools alone is unlikely to account for this difference between the elementary and middle school levels.
} 
opt out. These results confirm that distance is an important consideration for parents in choosing a school.

At both the elementary and middle school levels, the results for white students with college educated parents are consistent with outgroup avoidance and, because the predictions are the same, also with the neutral ethnocentrism. At the elementary school level, although the percent black in the assigned attendance zone does not independently influence the choice of college educated white students to opt out, the percent college educated in the assigned zone has a large and statistically significant negative effect. The results in the top panel indicate that a 10 percent difference in the percent of college educated parent's in the student's assigned school zone is associated with a difference in the likelihood that white students with college educated parents will opt out of slightly more than 10 percent. At the middle school level, the coefficient on percent black in the assigned school zone, which represents the combined effect of percent black, percent college educated, and average achievement levels, all of which are highly correlated, indicates that a 10 percent increase in the percent black increases the likelihood of opting out by 15.5 percent. In addition, at both the elementary and middle school levels, white students with college educated parents are more likely to opt out the nearer they live to a school with 15 percent more white students than their assigned school. After controlling for other factors, distance to schools with substantially more college educated students than their assigned school does not influence the choice of college educated, white families to opt out.

The second column examines the choices of white students whose parents do not have a college degree, and provides further support for the outgroup avoidance hypothesis. At both the elementary and middle school level, the likelihood of opting out for these students is higher the higher is the percent black in their attendance zone. At the elementary school level, but not the 
middle school level, white students whose parents lack a college degree are also more likely to opt out of their assigned school the nearer their home is to a school where the percent white is 15 points higher than in their assigned attendance zone.

While the outgroup avoidance hypothesis is silent about choices of black students and students whose parents do not have a college education, neutral ethnocentrism maintains that these students will seek out schools with more students like themselves. The support for this hypothesis provided by Table 3 is mixed. Two results support neutral ethnocentrism. At the elementary school level, white students whose parents lack a college degree are more likely to opt out of schools with a higher percentage of college educated parents, holding racial composition constant. Also, at the elementary school level, black students with college educated parents are less likely to opt out of schools with a higher percentage of black students and a higher percentage of college educated parents. ${ }^{10}$

Other results, however, are inconsistent with neutral ethnocentrism. The likelihood that black students whose parents lack a college education will opt out is higher the higher the percent black and lower the higher the percent of students with college educated parents. Rather, this result is consistent with the liberation model in that disadvantaged black students are able to opt out of schools with concentrations of disadvantaged students. Also, among middle school students, black students whose parents lack a college education are more likely to opt out the

\footnotetext{
${ }^{10}$ Middle school black students with college educated parents are more likely to opt out of a school as the percent black increases. This effect may simply be the result of omitting percent of students with college educated parents since the two variables are highly correlated. When percent of students with college educated parents in the assigned zone is included, without percent black, the estimate marginal effect is negative and highly significant, indicating that black, college educated parents are much less likely to opt out of assigned schools with above average percentages of college educated parents, which are also schools with below average percentages of black students.
} 
closer they live to a school with a percent college educated that is 10 percent higher than in their assigned attendance zone, which is consistent with the liberation model. ${ }^{11}$

In sum, the results of our analysis of the choice of advantaged students to opt out of one's assigned school is consistent with outgroup avoidance. Although the analysis also provides some evidence consistent with neutral ethnocentrism, overall support for neutral ethnocentrism is limited. In particular, there is no evidence of self-segregation among black students whose parents lack a college education, and in fact, the pattern of choices among this group is strongly at odds with self-segregation hypotheses. This result is not surprising given that even if students from disadvantaged backgrounds did prefer to be with peers more like themselves, they would face a tradeoff between that preference and any preference they might have for schools where student achievement is higher. The results suggest that while ethnocentric preferences influence the choices of some families, others use choice to escape schools with high concentrations of disadvantage, consistent with the liberation model.

\section{Schools Chosen by Those Who Opt Out}

The effects of school choice programs on patterns of segregation depend not only on which groups are more likely to opt out of their assigned school, but also on how the peer groups in the schools these students choose compare to those in the assigned schools that they are avoiding. Tables $4 \mathrm{~A}$ and $4 \mathrm{~B}$, which focus on students who have opted out of their assigned school, show how the peer environments compare. The comparisons are presented separately for black students, white students, students whose parents do not have a college degree, children of college educated parents, below average achievers, and above average achievers.

\footnotetext{
${ }^{11}$ A better test of neutral ethnocentrism might have been provided by including distance to nearest schools with less than 10 percent college educated parents for students with no college. However, this variable is highly correlated with average miles to nearest 3 schools, and its effects on the opt out decision cannot be reliably estimated.
} 
The results of these comparisons are consistent with outgroup avoidance behavior by advantaged groups. White students, students with college educated parents, and above average achievers all tend to choose schools with lower percentages of black students, higher percentages of students with college educated parents, and higher average levels of achievement. These tendencies hold both for elementary and middle school students. At the elementary school level, the tendency of white students to opt for schools with fewer black students is more marked than at the middle school level, and at the middle school level the tendency of students from advantaged groups to choose schools with more college educated parents and higher levels of achievement is more marked than at the elementary school level.

The evidence provided in Tables 4A and 4B for disadvantaged groups is consistent with the self- segregation model with regard to race and the liberation model with regard to parent's education and EOG test scores. At both the elementary and middle school levels, black choosers, on average, select schools with higher percentages of black students than in their assigned schools. This result provides some evidence of self-segregation, at least among those black students who opt out of their assigned school. Students whose parents do not have a college education, however, do not tend to choose schools with higher percentages of students similar to themselves on that dimension and below-average achievers do not choose schools with lower average levels of achievement. Rather, at both the elementary and middle school level, all three disadvantaged groups experience an improvement in peer quality as measured by percent of students with college educated parents and/or average test scores.

The average changes reported in Tables $4 \mathrm{~A}$ and $4 \mathrm{~B}$ hide some interesting variation within each group. Table 5 reports the share of students who make integrating choices and segregating choices measured as a percent of all students, both those who opt out of and those who remain in 
their assigned school. For white students, a racially integrating (segregating) choice is defined as a choice of a school that has at least 10 percent more (fewer) black students than the student's assigned school, and for black students, racially integrating (segregating) choices are defined as the choice of a school that is at least 10 percent fewer (more) black students than the student's assigned school. Similarly, we consider a choice to be integrating (segregating) by class if a student with college educated parents chooses a school that has 10 percent more (fewer) parents who are not college educated or if student whose parents do not have a college degree chooses a school that has 10 percent more (fewer) parents with a college education.

The liberation hypothesis maintains that school choice programs might reduce levels of school segregation relative to neighborhood assignment plans when school choices are generally less constrained than neighborhood choices. For this theory to hold true, a significant percentage of students would need to make what we have defined as integrating choices. The first column of Table 5 indicates that among elementary grade students, black students are almost twice as likely as white students to make racially integrating choices. This finding suggests that black families are more likely than white families to find themselves in more segregated environments than they might desire due to constraints on their residential location decisions. At the middle school level, roughly equal percentages of black and white students make racially integrating moves. The second column of Table 5 shows that, at both the elementary and middle school levels, students whose parents do not have a college degree are more than twice as likely to make choices that promote integration by class than students with college educated parents. For these black families and families whose parents lack a college education that find themselves in segregated settings because of constraints on their residential choices, school choice provides an important means of accessing more integrated schools. 
The third and fourth columns of Table 5 provide additional evidence of white flight and outgroup avoidance. Among students in grades 3 to 5, over 15 percent of white students make racially segregating moves and over 20 percent of students with college educated parents make choices that increase segregation by class. Among students in grades 6-8, over 10 percent of whites make racially segregating moves and over 30 percent of students with college educated parents make choices that increase segregation by class. Table 5 also provides some evidence of black self-segregation. About 18 percent of black students in grades 3 to 5, and about 14 percent in grades 6 to 8 , choose a school with a substantially higher percentage of black students than their assigned school, which is similar in magnitude to the self-segregation tendencies of white students. Students whose parents lack a college education are less likely to self-segregate. These students are about one half as likely at the elementary school level and less than one-third as likely at the middle school level as students with college educated parents to make a choice that increases segregation by class.

Taken together the figures in Table 5 indicate that any positive effects on integration achieved by weakening the link between housing market constraints and choice of school, are more than offset by negative effects of outgroup avoidance and ethnocentric preferences. While less than 10 percent of students at the elementary school level make racially integrating choices, more than 17 percent make racially segregating moves. At the elementary school level, 50 percent more students, and at the middle school level nearly three times as many students make choices that increase segregation by class as make choices that decrease segregation by class.

\section{A Counterfactual Comparison}

In this section we attempt to describe the overall effect of choice programs on school segregation in Durham. Specifically, we compare several measures of segregation given the 
actual distribution of students in 2002-03 to the measures of segregation that would have emerged if all students had attended the school to which they were geographically assigned. This counterfactual, in which all students attend their assigned schools, is probably not what we would see in the absence of school choice programs. About a quarter of elementary school students and nearly 30 percent of middle school students in Durham choose a school that does not have an assigned attendance zone. If magnet, year-round, and charter schools were not available, more zoned schools would be required, and as a result attendance zones would be drawn differently. In addition, student assignment policies can influence residential location decisions and decisions to opt out of the public schools in favor of private schools. Thus, we might expect to see a different pattern of residential segregation and private school enrollment if Durham choice programs were removed. Nonetheless, the counterfactual comparisons presented in this section provide a good indication of the potential of choice to increase or decrease segregation relative to strict geographic assignment policies.

We proceed by calculating a series of exposure indices given the observed distribution of students and comparing these to the same indices under the counterfactual. An exposure index measures the extent to which one group has contact with another, and can be defined for any pair of groups. Exposure rates can be interpreted as the percentage of students in Group B attending the same school as the typical member of Group A. Mathematically, the exposure rate is a weighted average of the percent of group B in each school, where shares of Group A are used as the weights. Higher values indicate more exposure to the other group. Exposure of Group A to members of its own group can be interpreted as a measure of group isolation. In this case higher values represent greater isolation. 
Table 6 examines measures of racial and ethnic isolation and exposure to whites. At the elementary level, the isolation of black, white, and Hispanic students is higher as the result of choice programs than they would be if all students attended their assigned school, and at the middle school level the isolation of whites and Hispanics is higher than under the counterfactual. At the elementary school level, the actual exposure of both black and Hispanic students to white students is lower than under the counterfactual. Even at the elementary school level, where the differences are larger, the differences between the actual measures of racial and ethnic segregation and the counterfactual measures are quite small. The segregating effects of the white flight and black self-segregation noted in Table 5, are to a considerable degree offset by students making racially integrating school choices. Nonetheless the bottom line is still clear: the availability of choice options in Durham has not reduced segregation either at the middle school level where magnet schools are specifically designed to appeal to white students or at the elementary level where existing levels of segregation under neighborhood assignment are relatively high.

Though the average effects on racial segregation are relatively small, effects may still be meaningful for the educational experiences of students, and particularly black students. In fact, with the choice programs, the percentage of black elementary school students who attend schools that are 75 percent or more black is 28.2 percent, which is 50 percent higher than the 18.4 percent we would see if all students were in their assigned school. Among third to fifth graders, the percent of black students in schools that are more than 90 percent black increases from 3.9 percent under the counterfactual to 7.2 percent as the result of school choice. School choice in Durham has, then, significantly increased the number of black students in highly segregated environments. 
As shown in Table 7, the overall effects of choice on segregation by parent's level of education are larger than for race. At the elementary school level there would be some segregation by parent's education level if all students attended their assigned school. Under the counterfactual, the percent of school peers with college educated parents is, on average, nearly 11 percent higher for students whose parents have a 4 year college degree than for students who parents have a high school degree and no college. Segregation by parent's education level, however, is even greater as a result of school choice. Given the actual distribution of students across schools, the percent of school peers with college educated parents is nearly 20 percent higher for students whose parents have a four year degree than for students who parents have a high school diploma and no college. Also, in the right hand panel of Table 7, we see that students whose parents are high school dropouts are more concentrated than they would be under the counterfactual.

At the middle school level, there would be virtually no segregation by parent education if students attended their assigned school. Under the counterfactual, students would attend schools with nearly equal percentages of college educated parents, regardless of their own parent's education level. In actuality, as a result of parental choice, there is significant segregation by parent education. The percent of school peers with a college educated parent is, on average, more than 10 percentage points higher in the schools attended by students whose own parents are college educated than in the schools attended by students who parents do not have a college degree. Children of high school dropouts are also more concentrated at the middle school level as a result of parental choice.

Finally, in Table 8, we explore how the availability of choice programs changes the average achievement levels of the peer groups of various types of students relative to that of the 
peer groups they would have had if all students had remained in their assigned zones. ${ }^{12}$ The table reports results for the average tests scores of peers, and the fractions of low or superior performers. At the elementary school level, disadvantaged student groups (blacks, Hispanics and those with parents with less than a college degree) all end up in schools with lower average levels of peer achievement, more low performing peers, and fewer high achieving peers as a result of choice. White students and students with college educated parents, in contrast, end up in schools with higher achieving peers, fewer low performers and more high performers. At the middle school level, Hispanic students and students whose parents do not have a college degree end up with lower achieving peers, and white students and students with college educated parents with higher achieving peers, than they would if all students attended their assigned school. Choice does not appear to change the achievement level of peers for black middle school students.

These findings suggest that the correlation of class and race with school quality as measured by student achievement may increase with the availability of choice. This phenomenon may help to reinforce the perception that racial and ethnic composition is a good predictor of school quality, and thereby lead to long term increases in the level of segregation above those identified in this study. The extent to which segregation may further increase in the long run, however, depends, on whether the relatively small differences in peer groups reported here are large enough to affect white parents' perceptions concerning the quality of predominantly minority schools, a question that is beyond the scope of this paper.

\footnotetext{
12 The test scores are normalized to the state average, which is well above the average scores in the Durham School district. This explains the negative average achievement of peers for all groups in Table 8.
} 


\section{Conclusions}

We find evidence that substantial numbers of white families use school choice programs to avoid schools with concentrations of racial minorities, and that some black families use school choice programs to choose more racially isolated environments. However, the segregating effects of such choices are largely offset by the small set of students who make racially integrating choices, especially at the middle school level where the district has had more success establishing magnet schools attractive to white families. We conclude that while school choice programs in Durham have increased the racial segregation of schools the overall effect has been quite small.

In contrast, school choice programs in Durham have had larger effects on segregation by class and student achievement. Substantial proportions of students with college educated parents opt out of schools with lower percentages of college educated parents and choose schools with higher percentages of college educated parents. In contrast, only a small group of parents who do not have a college education choose schools with higher percentages of college educated students and higher achievement levels than in their assigned school. While the peer environment clearly improves for disadvantaged students who opt out of their assigned school, this positive outcome is overwhelmed by the larger improvements for advantaged students who opt out, and the net effect is a significant increase in stratification across schools by class and ability.

Whether the results for Durham can be generalized to other areas and districts is an open question. Several considerations, however, suggest that school choice programs are likely to have similar effects elsewhere. Despite important differences in the context of elementary and middle schools in Durham, school choice results in slightly more segregation by race and 
significantly more segregation by class and ability at both levels. Also, Saporito (2003) using similar data on high school students in Philadelphia finds that school choice programs increase segregation by socioeconomic status.

Perhaps most telling, the results for Durham are consistent with what we would expect given reasonable assumptions about how preferences for school characteristics are distributed. Given the correlation between family background characteristics and school achievement, and the links between student composition and school quality, any preference students from advantaged backgrounds might have to attend schools with peers from a similar background will be reinforced by preferences for high quality schools or schools with high average levels of achievement. Indeed, many parents might not even distinguish between schools with advantaged students, schools with high levels of achievement, and schools with high quality instruction. As a result, we can expect a high proportion of students from advantaged backgrounds to opt out of schools with concentrations of disadvantaged students and into schools with high percentages of advantaged peers and high achievement levels. Such choices increase segregation by race, class, and achievement. Students from disadvantaged backgrounds in contrast often face a tradeoff between attending a school with more peers who share a similar background and schools with high levels of achievement. As a result, they can be expected to opt for schools with more advantaged peers and higher levels of achievement less frequently than students from advantaged backgrounds. Thus, the integrating effects of choice by disadvantaged students seeking higher achieving schools are outweighed by the segregating effects of choices made by students from advantaged backgrounds.

Our results suggest that, in the absence of direct controls over the student composition of particular schools, school choice programs of the type used in Durham, are unlikely to 
decrease student segregation by race, class, or achievement relative to neighborhood assignment policies. School choice programs might serve other legitimate purposes, but advocates of integrated schools are unlikely to find the solutions they seek in these programs.

\section{References}

Armor, David J. and Brett M. Peiser. 1998. “Interdistrict Choice in Massachusetts.” Pp. 157-86 in Learning From School Choice, edited by P.E. Peterson \& B.C. Hassel. Washington, DC: Brookings Institution Press.

Bayer, Patrick, Rober McMillan, and Kim Rueben. 2005. "Residential Segregation in General Equilibrium.” National Bureau of Economic Research, Working Paper 11095.

Bifulco, Robert and Helen F. Ladd. 2007. "School Choice, Racial Segregation and Test-Score Gaps: Evidence from North Carolina's Charter School Program.” Journal of Policy Analysis and Management, 26: 31-56.

Bobo, Lawrence. 1999. "Prejudice as Group Position: Microfoundations of a Sociological Approach to Race and Race Relations.” Journal of Social Issues 55:445-72.

Bobo, Lawrence and Camille Zubrinsky. 1996. "Attitudes on Residential Integration: Perceived Status Differences, Mere In-Group Preference, or Racial Prejudice.” Social Forces 74:883-909.

Bonilla-Silva, Eduardo. 1996. "Rethinking Racism: Toward a Structural Interpretation." American Sociological Review 62:465-80.

Brunner, Eric, Jennifer Imazeki, and Stephen L. Ross. 2006. "Universal Vouchers and White Flight.” University of Connecticut Working Paper.

Campbell, J.M., C.M. Hombo, and J. Mazzeo. 2000. NAEP 1999 Trends in Academic Progress: Three Decades of Student Performance. NCES 2000469.

Clapp, John, Anupam Nanda, and Stephen L. Ross. In Press. "Which School Attributes Matter? The Influence of School District Performance and Demographic Composition on Property Values.” Journal of Urban Economics.

Clark, William.1992. "Residential Preferences and Residential Choices in a Multiethnic Context.” Demography 29:451-66.

Clotfelter, Charles T. 1979. "Urban School Desegregation and Declines in White Enrollment: A Reexamination.” Journal of Urban Economics 6:352-70.

---------. 2004. After Brown: The Rise and Retreat of School Desegregation. Princeton, NJ: Princeton University Press. 
Clotfelter, Charles T., Helen F. Ladd, and Jacob L. Vigdor. 2006. “Teacher-Students Matching and the Assessment of Teacher Effectiveness.” Journal of Human Resources 41:778-820.

Coleman, James S., Sara D. Kelly, and John A. Moore. 1975. Trends in School Segregation, 1968-73. Urban Institute Paper no. 722-03-01.

Cullen, Julie Berry, Brian A. Jacob, and Steven Levitt. 2005. “The Impact of School Choice on Student Outcomes: An Analysis of the Chicago Public Schools.” Journal of Public Economics 89:729-60.

Cutler, David M., Edward L. Glaeser, \& Jacob L. Vigdor. 1999. “The Rise and Decline of the American Ghetto.” Journal of Political Economy 107:455-506.

Downes, Thomas A. and Jeffrey E. Zabel. The Impact of School Characteristics on Housing Prices: Chicago 1987-1991. Journal of Urban Economics 52: 1-25.

Duncan, Greg and Jeanne Brooks-Gunn (eds.) 1997. Consequences of Growing Up Poor. New York: Russell Sage Foundation.

Ellen, Ingrid Gould. 2000. Sharing America's Neighborhoods. Cambridge, MA: Harvard University Press.

Farley, Reynolds and William H. Frey. 1994. "Changes in the Segregation of Whites from Blacks during the 1980s: Small Steps Toward a More Integrated Society." American Sociological Review 59:23-45.

Farley, Reynolds, Charlotte Steeh, Maria Kryson, Tara Jackson, and Keith Reeves. 1994. "Stereotypes and Segregation: Neighborhoods in the Detroit Area." American Journal of Sociology 100:750-80.

Ferguson, Ronald. 2001. "A Diagnostic Analysis of Black-White GPA Disparities in Shaker Heights, Ohio.” Brookings Papers on Education Policy.

Galster, George. 1982. "Black and White Preferences for Neighborhood Racial Composition. AREUEA Journal 10:39-66.

Hastings, Justine S., Thomas J. Kane, and Douglas O. Staiger. (2006). "Parental preferences and school competition: Evidence from a public school choice program.” National Bureau of Economic Research Working Paper No. 11805.

Henig, Jeffrey. 1996. "The Local Dynamics of Choice: Ethnic Preferences and Institutional Responses.” Pp. 95-117 in Who Chooses? Who Loses? Culture, Institutions and the Unequal Effects of School Choice, edited by B. Fuller and R. Elmore. New York: Teachers College Press.

Iceland, John. 2004. "Beyond Black and White: Metropolitan Residential Segregation in Multiethnic America.” Social Science Research 33:248-271. 
Ihlanfeldt, Keith R. and Benjamin Scafidi. 2002. "Black Self-Segregation as a Cause of Housing Segregation: Evidence from the Multi-City Study of Urban Inequality." Journal of Urban Economics 51:366-90.

Jencks, Christopher Jencks \& Meredith Phillips. 1998. "Introduction.” Pp. 1-51 in The BlackWhite Test Score Gap, edited by C. Jencks \& M. Phillips. Washington, DC: Brookings Institution Press.

Kahlenberg, Richard. 2001. All Together Now: Creating Middle Class Schools through Public School Choice. Washington, D.C: Brookings Institution Press.

Kain, Thomas J., Douglas O. Staiger, and Stephanie K. Reigg. 2005. School Quality, Neighborhod and Housing Prices: The Impacts of School Desegregation. NBER Working Paper \#11347.

King, T.A. and Peter Mieskowski. 1973. "Racial Discrimination, Segregation, and the Price of Housing.” Journal of Political Economy 81:590-606.

Klietz, Bretton, Gregory R. Weiher, Kent L. Tedin, and Richard Matland. 2000. "Choice, Charter Schools, and Household Preferences.” Social Science Quarterly 81:846-54.

Krysan, Maria. 2002.”Whites Who Say They'd Flee: Who Are They, and Why Would They Leave?” Demography 39:675-96.

Krysan, Maria \& Reynolds Farley. (2002). "The Residential Preferences of Blacks: Do They Explain Persistent Segregation.” Social Forces 80:937-80.

Lankford, Hamilton, E.S. Lee, and James Wyckoff. 1995. "An Analysis of Elementary and Secondary School Choice.” Journal of Urban Economics, 38:236-51.

Lankford, Hamilton, Susanna Loeb, and James Wyckoff. 2002. "Teacher Sorting and the Plight of Urban Schools: A Descriptive Analysis.” Education Evaluation and Policy Analysis, 24:3762.

Lankford, Hamilton and James Wyckoff. 1999. "The Effects of School Choice on Residential Location and the Racial Segregation of Students.” Albany: Departments of Economics and Public Administration and Policy, State University of New York at Albany.

Lazear, Edward P. 2001. “Education Production.” Quarterly Journal of Economics 116:777-803.

Massey, Douglas. 2001. "Residential Segregation and Neighborhood Conditions in U.S. Metropolitan Areas.” Pp. 391-434 in America Becoming: Racial Trends and Their Consequences, edited by Neil J. Smelser, William Julius Wilson, and Faith Mitchell. Washington, DC: National Academy Press. 
Ross, Stephen L. 2008. "The Continuing Practice and Impact of Discrimination." In Segregation: The Rising Costs for American, edited by James Carr and Nandini Kutty. London: Routledge, Inc.

Ross, Stephen L. and Margery A. Turner. 2005. "Housing Discrimination in Metropolitan American: Explaining Changes between 1989 and 2000.” Social Problems 52, 152-180.

Rossell, Christine H., and David J. Armor. 1996. "The Effectiveness of School Desegregation Plans, 1968-1991.” American Politics Quarterly 24:267-302.

Saporito, Salvatore. 2003. "Private Choices, Public Consequences: Magnet School Choice and Segregation by Race and Poverty.” Social Problems 50, 181-203.

Schelling, Thomas. 1971. "Dynamic Models of Segregation.” Journal of Mathematical Sociology 1:143-86.

Schneider, Mark and Jack Buckley. 2002. What Do Parents Want From Schools? Evidence from the Internet. Educational Evaluation and Policy Analysis, 24:133-44.

Schneider, Mark, Paul Teske, and Melissa Marschall. 2000. Choosing Schools: Consumer Choice and The Quality of American Schools. Princeton, NJ: Princeton University Press.

Tauber, Karl and David James. 1982. "Racial Segregation Among Public and Private Schools.” Sociology of Education 55:133-43.

Timberlake, Jeffrey. 2000. "Still Life in Black and White: Effects of Racial and Class Attitudes on Prospects for Residential Integration in Atlanta.” Sociological Inquiry 70:420-45.

Viteritti, Joseph P. 1999. Choosing Equality: School Choice, the Constitution, and Civil Society. Washington, DC: Brookings Institution Press.

Welch, Finis and Audrey Light. 1987. New Evidence on School Desegregation. Washington, DC: U.S. Commission on Civil Rights (June).

Wells, Amy Stuart and Robert Crain. 1992. "Do Parents Choose School Quality or School Status: A Sociological Theory of Free Market Education.” Pp. 174-96 in The Choice Controversy, edited by P. Cookson. Newbury Park, CA: Corwin Press, Inc.

Yinger, John. 1978. “The Black-White Price Differential in Housing: Some Further Evidence.” Land Economics 54:187-206.

Yinger, John. 1995. Closed Doors, Opportunities Lost: The Continuing Costs of Housing Discrimination. New York: Russell Sage Foundation. 
Table 1. Summary Information on Durham Students, 2002-03

\begin{tabular}{|c|c|c|c|c|}
\hline & \multicolumn{2}{|c|}{ Grade 3-5 } & \multicolumn{2}{|c|}{ Grades 6-8 } \\
\hline & All students & $\begin{array}{c}\text { Students } \\
\text { with Address } \\
\text { Data }\end{array}$ & All students & $\begin{array}{c}\text { Students } \\
\text { with Address } \\
\text { Data }\end{array}$ \\
\hline \multicolumn{5}{|l|}{ Enrollment } \\
\hline Total Number & 8049 & 7715 & 7421 & 7204 \\
\hline In Assigned School & 4813 & 4747 & 4298 & 4236 \\
\hline In a Magnet School & 997 & 991 & 1024 & 1019 \\
\hline Transferred to Regular School ${ }^{a}$ & 1274 & 1274 & 747 & 747 \\
\hline Transferred to Year-Round School & 495 & 492 & 751 & 742 \\
\hline In a Charter School & 465 & 211 & 377 & 261 \\
\hline In an Alternative School & 5 & 0 & 224 & 199 \\
\hline \multicolumn{5}{|l|}{ Race/Ethnicity } \\
\hline \% Black & 60.5 & 60.1 & 60.9 & 60.7 \\
\hline$\%$ White & 25.2 & 25.4 & 27.8 & 28.1 \\
\hline \% Hispanic & 8.9 & 9.1 & 6.8 & 6.7 \\
\hline$\%$ Multiracial & 2.7 & 2.8 & 2.5 & 2.5 \\
\hline$\%$ Asian & 2.3 & 2.4 & 1.8 & 1.8 \\
\hline$\%$ Native American & 0.3 & 0.3 & 0.2 & 0.2 \\
\hline \multicolumn{5}{|l|}{ Parents' Education } \\
\hline \% Less than High School & 8.3 & 8.3 & 6.5 & 6.2 \\
\hline \% High School & 53.4 & 53.5 & 45.6 & 45.8 \\
\hline \% Two-Year College & 12.1 & 11.9 & 14.5 & 14.3 \\
\hline \% Four-Year College & 26.2 & 26.3 & 33.5 & 33.7 \\
\hline \multicolumn{5}{|l|}{ Achievement Level } \\
\hline$\%$ Inconsistent Mastery & 23.5 & 23.0 & 32.1 & 31.6 \\
\hline$\%$ Consistent Mastery & 47.8 & 47.8 & 42.2 & 42.3 \\
\hline$\%$ Superior Performance & 28.6 & 29.2 & 25.7 & 26.1 \\
\hline
\end{tabular}

a. Students who attend a zoned school other than the one to which they are assigned. Only students with address data could be identified as transfer requests. 
Table 2: Summary of Variables Used in Probit Analysis, Means (\& Standard Deviations)

\begin{tabular}{|c|c|c|c|c|}
\hline & \multicolumn{4}{|c|}{ Grades 3-5 } \\
\hline & $\begin{array}{l}\text { White \& } \\
\text { College }\end{array}$ & $\begin{array}{l}\text { White \& } \\
\text { No College }\end{array}$ & $\begin{array}{l}\text { Black \& } \\
\text { College }\end{array}$ & $\begin{array}{l}\text { Black \& } \\
\text { No College }\end{array}$ \\
\hline Number of Observations & 1201 & 760 & 1479 & 3156 \\
\hline Student opted out of assigned school & $0.331(0.471)$ & $0.262(0.440)$ & $0.451(0.498)$ & $0.446(0.497)$ \\
\hline Average achievement & $0.734(0.787)$ & $0.235(0.882)$ & $-0.147(0.799)$ & $-0.650(0.803)$ \\
\hline$\%$ black in assigned zone & $46.5(19.0)$ & $53.7(17.0)$ & $64.4(15.2)$ & $65.7(14.5)$ \\
\hline$\%$ college ed. parents in assigned zone & $48.0(14.5)$ & $38.2(12.4)$ & $40.0(13.7)$ & $33.4(13.2)$ \\
\hline $\begin{array}{l}\text { Miles to nearest school with } 15 \% \text { more } \\
\text { white students }\end{array}$ & $2.75(1.83)$ & $2.97(2.19)$ & $2.37(1.64)$ & $2.04(1.54)$ \\
\hline $\begin{array}{l}\text { Miles to nearest school with } 15 \% \text { more } \\
\text { black students }\end{array}$ & $2.40(1.56)$ & $2.84(1.68)$ & $1.40(1.46)$ & $1.05(1.41)$ \\
\hline $\begin{array}{l}\text { Miles to nearest school with } 10 \% \text { more } \\
\text { college educated parents }\end{array}$ & $3.92(4.85)$ & $3.59(4.01)$ & $2.18(1.83)$ & $1.93(1.90)$ \\
\hline Miles to assigned school & $1.64(1.64)$ & $1.60(1.46)$ & $1.27(1.24)$ & $1.66(1.42)$ \\
\hline \multirow[t]{3}{*}{ Average miles to nearest 3 schools } & $2.25(1.54)$ & $2.18(1.41)$ & $1.27(0.89)$ & $1.05(0.96)$ \\
\hline & \multicolumn{4}{|c|}{ Grades 6-8 } \\
\hline & $\begin{array}{l}\text { White \& } \\
\text { College }\end{array}$ & $\begin{array}{l}\text { White \& } \\
\text { No College }\end{array}$ & $\begin{array}{l}\text { Black \& } \\
\text { College }\end{array}$ & $\begin{array}{l}\text { Black \& } \\
\text { No College }\end{array}$ \\
\hline Number of Observations & 1465 & 558 & 1699 & 2676 \\
\hline Student opted out of assigned school & $0.390(0.488)$ & $0.281(0.450)$ & $0.483(0.500)$ & $0.361(0.480)$ \\
\hline Average achievement & $0.627(0.794)$ & $-0.026(0.945)$ & $-0.261(0.819)$ & $-0.813(0.805)$ \\
\hline$\%$ black in assigned zone & $57.1(8.7)$ & $60.9(9.2)$ & $62.3(8.7)$ & $61.9(8.7)$ \\
\hline $\begin{array}{l}\text { Miles to nearest school with } 15 \% \text { more } \\
\text { white students }\end{array}$ & $5.55(3.18)$ & $5.43(3.37)$ & $3.80(2.93)$ & $3.70(3.11)$ \\
\hline $\begin{array}{l}\text { Miles to nearest school with } 15 \% \text { more } \\
\text { black students }\end{array}$ & $3.15(2.23)$ & $3.05(1.96)$ & $1.69(1.66)$ & $1.34(1.51)$ \\
\hline $\begin{array}{l}\text { Miles to nearest school with } 10 \% \text { more } \\
\text { college educated parents }\end{array}$ & $3.31(1.54)$ & 3.19 (1.54) & $2.37(1.54)$ & $1.94(1.47)$ \\
\hline Miles to assigned school & $3.29(1.99)$ & $3.17(1.78)$ & $3.28(1.67)$ & $3.52(1.72)$ \\
\hline Average miles to nearest 3 schools & $3.57(1.98)$ & $3.39(1.79)$ & $2.11(1.33)$ & $1.75(1.23)$ \\
\hline
\end{tabular}


Table 3: The relationship between student characteristics, attendance zone characteristics, and the decision to opt out

\begin{tabular}{|c|c|c|c|c|}
\hline & \multicolumn{4}{|c|}{ Grades 3-5 } \\
\hline & $\begin{array}{l}\text { White \& } \\
\text { College }\end{array}$ & $\begin{array}{l}\text { White \& } \\
\text { No College }\end{array}$ & $\begin{array}{l}\text { Black \& } \\
\text { College }\end{array}$ & $\begin{array}{l}\text { Black \& } \\
\text { No College }\end{array}$ \\
\hline Average achievement & -0.020 & 0.007 & 0.006 & -0.019 \\
\hline Miles to assigned school & $0.085^{\star \star}$ & $0.074^{\star \star}$ & $0.034^{\star \star}$ & $0.062^{\star *}$ \\
\hline Average miles to nearest 3 schools & $-0.064^{\star \star}$ & $-0.046^{\star *}$ & -0.038 & $-0.071^{* *}$ \\
\hline$\%$ black in assigned zone & -0.017 & $0.541^{\star \star}$ & $-0.503^{\star \star}$ & $0.364^{\star \star}$ \\
\hline$\%$ college ed. parents in assigned zone & $-1.040 * \star$ & $0.372^{*}$ & $-1.235^{\star \star}$ & $-0.403^{\star \star}$ \\
\hline $\begin{array}{l}\text { Miles to nearest school with } 15 \% \text { more } \\
\text { white students }\end{array}$ & $-0.028 * *$ & $-0.032^{\star *}$ & & \\
\hline $\begin{array}{l}\text { Miles to nearest school with } 15 \% \text { more } \\
\text { black students }\end{array}$ & & & -0.009 & -0.005 \\
\hline \multirow[t]{3}{*}{$\begin{array}{l}\text { Miles to nearest school with } 10 \% \text { more } \\
\text { college educated parents }\end{array}$} & 0.001 & -0.002 & -0.013 & -0.008 \\
\hline & \multicolumn{4}{|c|}{ Grades 6-8 } \\
\hline & $\begin{array}{l}\text { White \& } \\
\text { College }\end{array}$ & $\begin{array}{l}\text { White \& } \\
\text { No College }\end{array}$ & $\begin{array}{l}\text { Black \& } \\
\text { College }\end{array}$ & $\begin{array}{l}\text { Black \& } \\
\text { No College }\end{array}$ \\
\hline Average achievement & $0.068^{\star *}$ & $0.079 * *$ & $0.074^{* *}$ & $0.080^{\star \star}$ \\
\hline Miles to assigned school & $0.036^{\star *}$ & $0.055^{\star \star}$ & 0.000 & -0.001 \\
\hline Average miles to nearest 3 schools & $-0.040 * \star$ & $-0.037^{\star \star}$ & $-0.042^{\star \star}$ & $-0.048^{\star \star}$ \\
\hline$\%$ black in assigned zone & $1.550^{\star \star}$ & $0.676^{\star \star}$ & $0.803^{* *}$ & $0.336^{* *}$ \\
\hline $\begin{array}{l}\text { Miles to nearest school with } 15 \% \text { more } \\
\text { white students }\end{array}$ & $-0.035^{\star \star}$ & 0.000 & & \\
\hline $\begin{array}{l}\text { Miles to nearest school with } 15 \% \text { more } \\
\text { black students }\end{array}$ & & & -0.007 & 0.010 \\
\hline $\begin{array}{l}\text { Miles to nearest school with } 10 \% \text { more } \\
\text { college educated parents }\end{array}$ & 0.014 & -0.007 & 0.000 & $-0.019^{\star *}$ \\
\hline
\end{tabular}

Estimates are marginal effects at sample mean derived from probit model using indicator of choice to opt out as dependent variable. * statistically significant at 0.10 level, ** statistically significant at 
Table 4A: Differences in Peer Environment for Students Opting Out of Their Assigned School, Grade 3-5

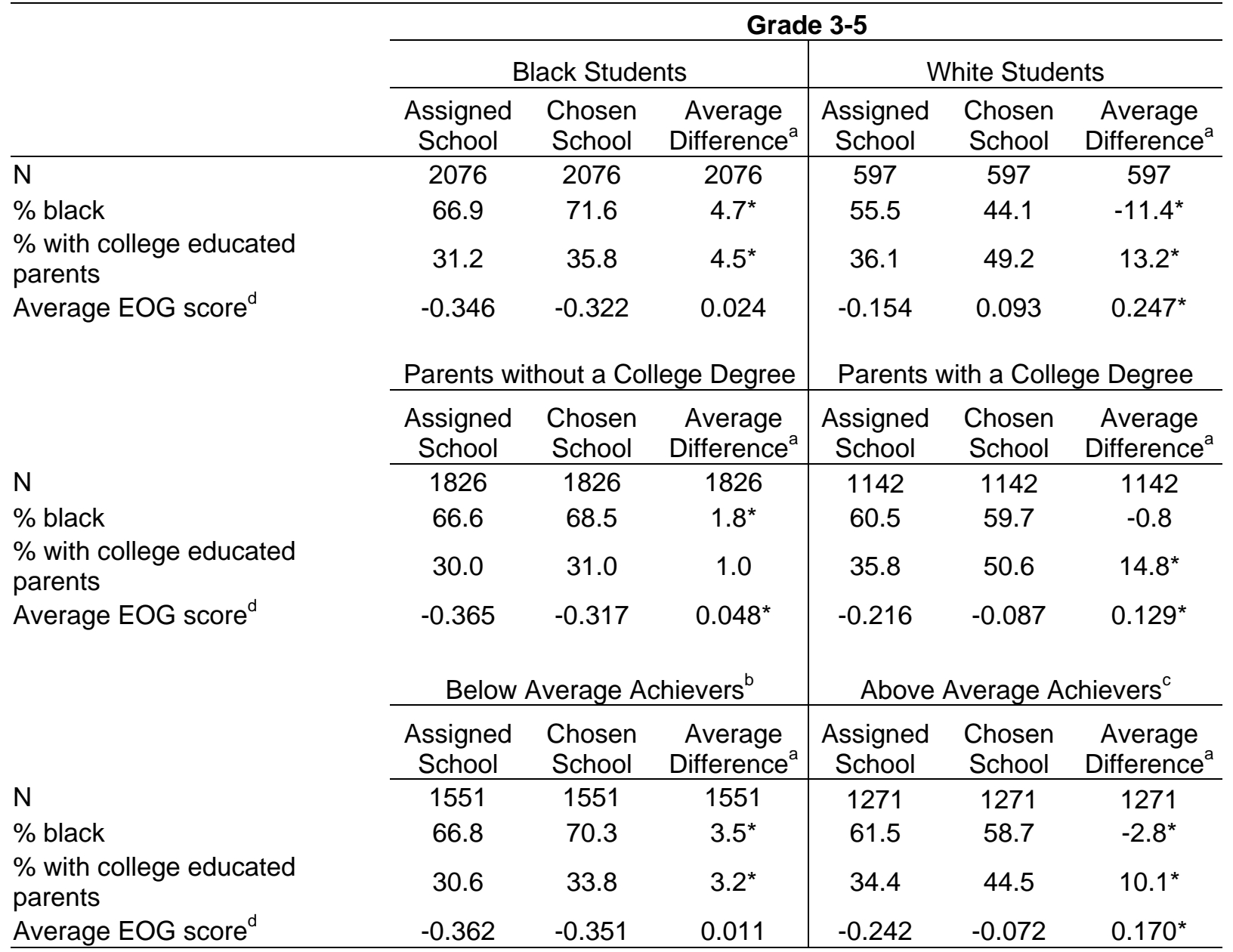

a. Differences that are statistically significant at 0.01 level based on two-tailed t-test are marked with *

b. Student's with standardized EOG reading test score less than zero.

c. Student's with standardized EOG reading test scores equal to or greater than zero.

d. Average of math and reading EOG score normed to grade specific statewide average. District-wide, average test scores in Durham are lower than in the rest of the state, hence the negative average EOG scores across all groups. 
Table 4B: Differences in Peer Environment for Students Opting Out of Their Assigned School, Grade 6-8

\begin{tabular}{|c|c|c|c|c|c|c|}
\hline & \multicolumn{3}{|c|}{ Blacks } & \multicolumn{3}{|c|}{ Whites } \\
\hline & $\begin{array}{l}\text { Assigned } \\
\text { School }\end{array}$ & $\begin{array}{l}\text { Chosen } \\
\text { School }\end{array}$ & $\begin{array}{c}\text { Average } \\
\text { Difference }^{\mathrm{a}}\end{array}$ & $\begin{array}{l}\text { Assigned } \\
\text { School }\end{array}$ & $\begin{array}{l}\text { Chosen } \\
\text { School }\end{array}$ & $\begin{array}{c}\text { Average } \\
\text { Difference }^{a}\end{array}$ \\
\hline $\mathrm{N}$ & 1788 & 1788 & 1788 & 728 & 728 & 728 \\
\hline$\%$ black & 61.9 & 65.2 & $3.3^{\star}$ & 59.6 & 56.2 & $-3.4^{\star}$ \\
\hline $\begin{array}{l}\% \text { with college educated } \\
\text { parents }\end{array}$ & 41.7 & 53.2 & $11.5^{\star}$ & 43.7 & 62.1 & $18.5^{\star}$ \\
\hline \multirow[t]{3}{*}{ Average EOG score $^{d}$} & -0.427 & -0.164 & $0.263^{*}$ & -0.399 & -0.039 & $0.360^{*}$ \\
\hline & \multicolumn{3}{|c|}{ Parents without a College Degree } & \multicolumn{3}{|c|}{ Parents with a College Degree } \\
\hline & $\begin{array}{l}\text { Assigned } \\
\text { School }\end{array}$ & $\begin{array}{l}\text { Chosen } \\
\text { School }\end{array}$ & $\begin{array}{c}\text { Average } \\
\text { Difference }^{\mathrm{a}}\end{array}$ & $\begin{array}{l}\text { Assigned } \\
\text { School }\end{array}$ & $\begin{array}{l}\text { Chosen } \\
\text { School }\end{array}$ & $\begin{array}{c}\text { Average } \\
\text { Difference }^{a}\end{array}$ \\
\hline $\mathrm{N}$ & 1261 & 1261 & 1261 & 1508 & 1508 & 1508 \\
\hline$\%$ black & 61.5 & 65.5 & $4.0^{*}$ & 61.0 & 60.0 & 1.0 \\
\hline $\begin{array}{l}\% \text { with college educated } \\
\text { parents }\end{array}$ & 42.1 & 44.1 & $2.0^{\star}$ & 42.3 & 65.0 & $22.7^{\star}$ \\
\hline \multirow[t]{3}{*}{ Average EOG score $^{d}$} & -0.435 & -0.207 & $0.228^{*}$ & -0.413 & -0.061 & $0.352^{\star}$ \\
\hline & \multicolumn{3}{|c|}{ Below Average Achievers ${ }^{b}$} & \multicolumn{3}{|c|}{ Above Average Achievers ${ }^{c}$} \\
\hline & $\begin{array}{l}\text { Assigned } \\
\text { School }\end{array}$ & $\begin{array}{l}\text { Chosen } \\
\text { School }\end{array}$ & $\begin{array}{c}\text { Average } \\
\text { Difference }^{a}\end{array}$ & $\begin{array}{l}\text { Assigned } \\
\text { School }\end{array}$ & $\begin{array}{l}\text { Chosen } \\
\text { School }\end{array}$ & $\begin{array}{c}\text { Average } \\
\text { Difference }^{\mathrm{a}}\end{array}$ \\
\hline $\mathrm{N}$ & 1225 & 1225 & 1225 & 1453 & 1453 & 1453 \\
\hline$\%$ black & 61.3 & 64.8 & $3.5^{\star}$ & 61.2 & 60.7 & 0.5 \\
\hline $\begin{array}{l}\% \text { with college educated } \\
\text { parents }\end{array}$ & 42.2 & 51.9 & $9.7^{*}$ & 42.3 & 58.9 & $16.6^{\star}$ \\
\hline Average EOG score $^{d}$ & -0.427 & -0.239 & $0.188^{*}$ & -0.417 & -0.023 & $0.394^{*}$ \\
\hline
\end{tabular}

a. Differences that are statistically significant at 0.01 level based on two-tailed t-test are marked with *

b. Student's with standardized EOG reading test score less than zero.

c. Student's with standardized EOG reading test scores equal to or greater than zero.

d. Average of math and reading EOG score normed to grade specific statewide average 
Table 5: Integrative and Segregative Choices

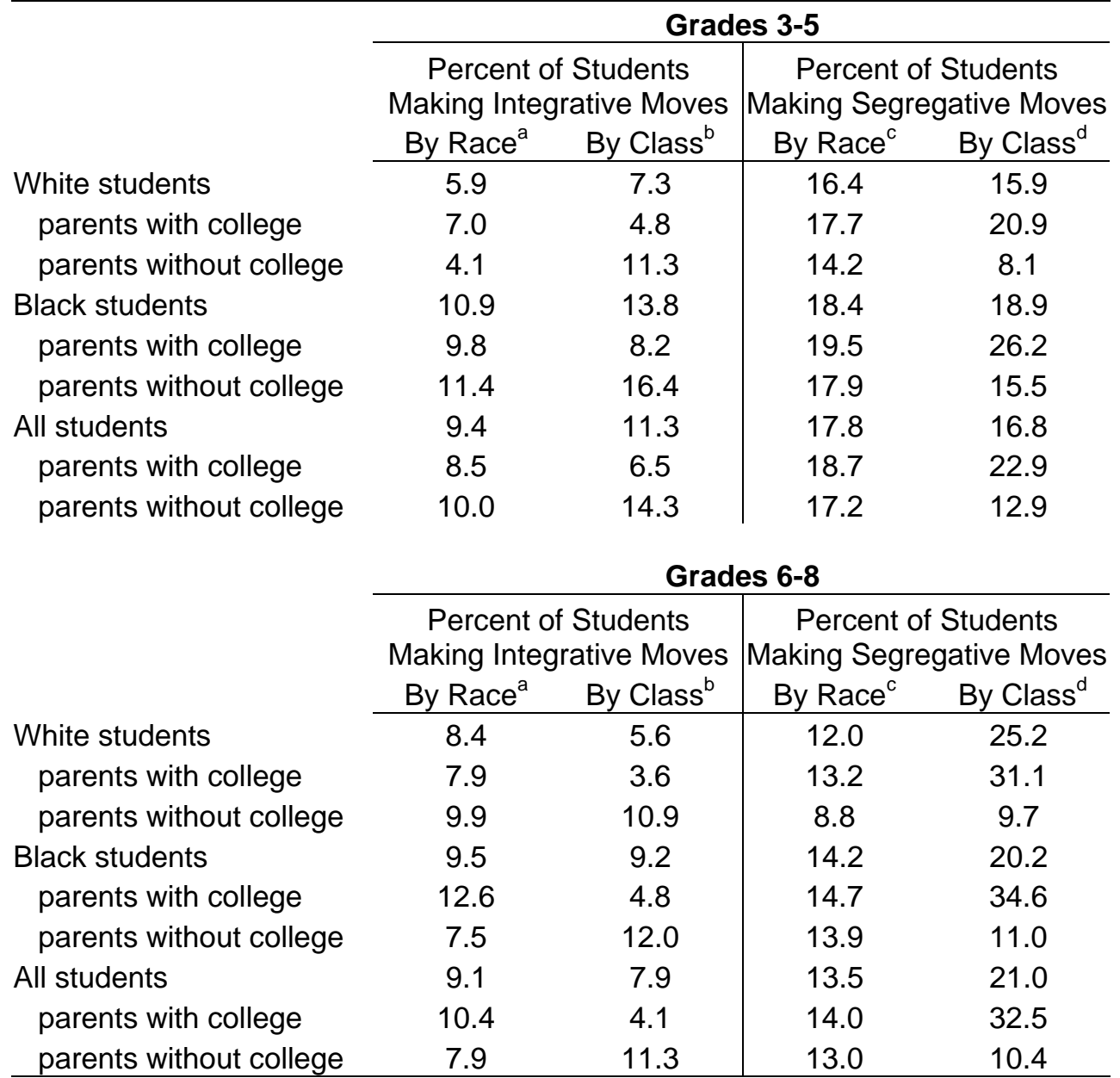

a. For white (black) students, racially integrating move is defined as a choice of a school with percent black (white) at least 10 points higher than in assigned school. Only defined for black and white students.

b. For students with (without) college educated parents, class integrating move is defined as a choice of a school where percent without (with) college educated parents black is at least 10 points higher than in assigned school.

c. For white (black) students, racially segregrating move is defined as a choice of a school with percent black (white) at least 10 points lower than in assigned school. Only defined for black and white students.

d. For students with (without) college educated parents, class segegrating move is defined as a choice of a school where percent without (with) college educated parents black is at least 10 points lower than in assigned school. 
Table 6: Racial and Ethnic Segregation, Actual Compared to Counterfactual

\begin{tabular}{|c|c|c|c|c|}
\hline & \multicolumn{4}{|c|}{ Grades 3-5 } \\
\hline & \multicolumn{2}{|c|}{ Isolation } & \multicolumn{2}{|c|}{ Exposure to Whites } \\
\hline & Actual & Counterfactual & Actual & Counterfactual \\
\hline \multicolumn{5}{|c|}{ Students Own Ethnicity } \\
\hline Black & 0.670 & $0.652^{\star}$ & 0.190 & $0.209^{*}$ \\
\hline White & 0.421 & $0.369^{*}$ & 0.421 & $0.369^{*}$ \\
\hline \multirow[t]{4}{*}{ Hispanic } & 0.158 & $0.131^{*}$ & 0.197 & 0.207 \\
\hline & \multicolumn{4}{|c|}{ Grades 6-8 } \\
\hline & \multicolumn{2}{|c|}{ Isolation } & \multicolumn{2}{|c|}{ Exposure to Whites } \\
\hline & Actual & Counterfactual & Actual & Counterfactual \\
\hline \multicolumn{5}{|c|}{ Students Own Ethnicity } \\
\hline Black & 0.621 & 0.620 & 0.264 & $0.290^{*}$ \\
\hline White & 0.421 & $0.369^{*}$ & 0.421 & $0.369^{\star}$ \\
\hline Hispanic & 0.092 & $0.079^{*}$ & 0.276 & 0.280 \\
\hline
\end{tabular}

Counterfactual is index computed with all students in their assigned neighborhood school.

* indicates that difference between actual and counterfactual is statistically significant at 0.01 level. 
Table 7: Exposure to Students with College Educated Parents, Actual Compared to Counterfactual

\begin{tabular}{|c|c|c|c|c|}
\hline & \multicolumn{4}{|c|}{ Grades 3-5 } \\
\hline & \multicolumn{2}{|c|}{$\begin{array}{l}\text { Exposure to College } \\
\text { Educated }\end{array}$} & \multicolumn{2}{|c|}{ Exposure to H.S. Dropouts } \\
\hline & Actual & Counterfactual & Actual & Counterfactual \\
\hline \multicolumn{5}{|c|}{ Education of Student's Own Parent } \\
\hline Less than High School & 0.291 & $0.329 *$ & 0.174 & $0.128^{*}$ \\
\hline High School & 0.318 & $0.349^{*}$ & 0.083 & 0.084 \\
\hline Two-Year College Degree & 0.440 & $0.397^{*}$ & 0.072 & 0.076 \\
\hline \multirow[t]{4}{*}{ Four-Year College Degree } & 0.515 & $0.458^{*}$ & 0.059 & $0.069 *$ \\
\hline & \multicolumn{4}{|c|}{ Grades 6-8 } \\
\hline & \multicolumn{2}{|c|}{$\begin{array}{l}\text { Exposure to College } \\
\text { Educated }\end{array}$} & \multicolumn{2}{|c|}{ Exposure to H.S. Dropouts } \\
\hline & Actual & Counterfactual & Actual & Counterfactual \\
\hline \multicolumn{5}{|c|}{ Education of Student's Own Parent } \\
\hline Less than High School & 0.423 & $0.479^{*}$ & 0.104 & $0.071^{*}$ \\
\hline High School & 0.437 & $0.476^{*}$ & 0.064 & 0.061 \\
\hline Two-Year College Degree & 0.538 & $0.475^{\star}$ & 0.055 & $0.062^{*}$ \\
\hline Four-Year College Degree & 0.544 & $0.489 *$ & 0.054 & $0.062^{*}$ \\
\hline
\end{tabular}

Counterfactual is index computed with all students in their assigned neighborhood school.

* indicates that difference between actual and counterfactual is statistically significant at 0.01 level. 
Table 8: Achievement of Peers, Actual Compared to Counterfactual

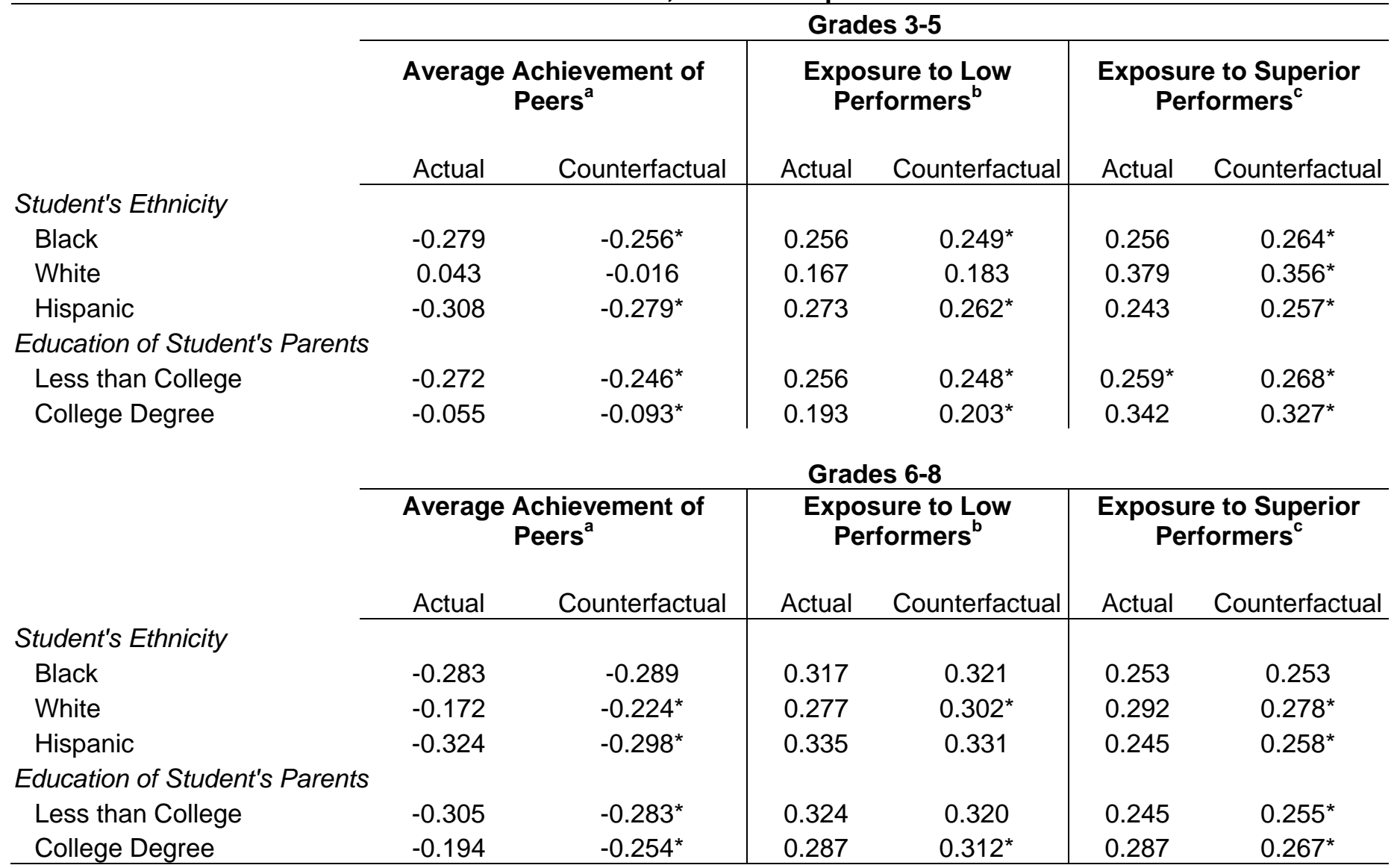

Counterfactual is index computed with all students in their assigned neighborhood school. * indicates that difference between actual and counterfactual is statistically significant at 0.01 level.

a. Average of math and reading EOG score of students in the same school and grade, normed to grade specific statewide average. District-wide, average test scores in Durham are lower than in the rest of the state, hence the negative average EOG scores across all groups.

b. Fraction of peers showing less than consistent mastery on either the EOG reading or EOG math test.

c. Fraction of peers showing superior performance on either the EOG reading or EOG math test. 